\title{
Influence of the Adsorption of Phycocyanin on the Performance in DSS Cells: and Electrochemical and QCM Evaluation
}

\author{
Paula Enciso ${ }^{1}$, Jean-David Decoppet ${ }^{2}$, Thomas Moehl ${ }^{2}$, Michael Grätzel ${ }^{2}$, Michael Wörner ${ }^{3}$ and \\ María Fernanda Cerdá ${ }^{1, *}$ \\ ${ }^{1}$ Laboratorio de Biomateriales, Facultad de Ciencias, Universidad de la República. Iguá 4225, 11400 \\ Montevideo, Uruguay \\ ${ }^{2}$ Ecole Polytechnique Federale de Lausanne, 1015 Lausanne, Switzerland \\ ${ }^{3}$ Karlsruher Institut für Technologie, Karlsruhe, Germany \\ *E-mail: fcerda@fcien.edu.uy
}

doi: $10.20964 / 110443$

Received: 5 February 2016 / Accepted: 20 February 2016 / Published: 1 April 2016

The influence of some coadsorbents and different $\mathrm{pH}$ values on the efficiency of DSS cells assembled with phycocyanin was evaluated using quartz crystal microbalance (QCM) and electrochemical techniques as impedance spectroscopy (EIS) and cyclic voltammetry (CV). Chlorophyll, heptadecanoic acid and 7.5 or $8.5 \mathrm{pH}$ values were applied when nanostructured $\mathrm{TiO}_{2}$ electrode was dipped in the dye solution. Best efficiency conversion values were obtained when using fatty acids as coadsorbents, reaching a conversion efficiency of $0.04 \%$ for open cells.

Keywords: DSSC, phycocyanin, coadsorbents, QCM, EIS

\section{FULL TEXT}

(C) 2016 The Authors. Published by ESG (www.electrochemsci.org). This article is an open access article distributed under the terms and conditions of the Creative Commons Attribution license (http://creativecommons.org/licenses/by/4.0/). 